\title{
INTRODUCTION: EXPLORING A NEW APPROACH TO SMALL-SCALE INDUSTRY
}

\author{
Jesper Rasmussen, Hubert Schmitz and Meine Pieter van Dijk
}

\section{PURPOSE OF THIS BULLETIN}

For more than a century, small-scale industry has been the weak and ugly duckling in the mainstream of the industrialisation debate. This has changed over recent years, small has not become beautiful wherever it appears, but it commands more respect and attention than it ever has. In the form of flexible specialisation, small-scale industry has demonstrated its economic and political strength, not in peripheral activities but in the engine room of capitalism; not in times of easy growth but in times of crisis. Let us explain.

One of the main themes in the current debate on industrialisation in advanced countries is the relative decline of Fordist mass production and expansion of activities based on less rigid and more adaptable structures, often referred to as flexible specialisation. Views differ on how far reaching this change is, whether it is discontinuous; how useful our concepts are to analyse it. But few would deny that there has been a significant change in industrial organisation in advanced countries. The purpose of this Bulletin is to examine the relevance of flexible specialisation for Third World industry. A common objective of all contributors is to explore how the insights of the approach can be used to inform research and policy making in industrial development of LDCs.

Flexible specialisation can take various forms. One can distinguish between a large firm variant and a small firm variant (and combinations of the two). The former exists where large firms decentralise and adopt new organisational techniques. Most articles in this Bulletin focus on the small firm variant, where flexible specialisation results from the clustering or networking of small firms. It was, in particular, the success of such practices in Europe during the 1970s and 1980s which has helped to put small firms at the centre of the industrialisation debate (see, for example, Pyke and Sengenberger 1992). In this Bulletin we ask whether such growth has also occurred in LDCs and what the conditions are which produce, modify or prevent such growth.

The remainder of this introduction to the Bulletin proceeds as follows: Section 2 sets out further what flexible specialisation means and what conceptual problems arise. Section 3 explains why a concern with flexible specialisation is important for LDCs. Section 4 draws out future challenges for the researcher. And finally Section 5 introduces the various contributions to this Bulletin.

\section{FLEXIBLE SPECIALISATION: WHAT DOES IT MEAN?}

Since the mid-1980s, the concept of flexible specialisation has become frequently used in the literature about industrial change in the developed countries. Originally coined by Piore and Sabel (1984), the concept has been used to capture new ways of organising industrial production, which allegedly differ from the general Fordist pattern of post-war industrial development.

Flexible specialisation has, however, been used in various ways and for various purposes, as a result of which the debate has often been confusing. Is it a macro or micro level concept? Does it apply to both small and large enterprises? Is it both analytical and prescriptive?

As emphasised by some of the main advocates, the flexible specialisation concept can capture changes at both the macro and micro level (Hirst and Zeitlin 1991). At the macro level, flexible specialisation encapsulates the move from a dominant mass production system, where stable markets, factor-cost reductions, and economies of scale were key variables, to more diversified and ever-changing markets, products, and production processes, where flexibility and innovation occupy centre stage.

This has ramifications at the micro level. Here flexible specialisation is used to capture a new type of industrial organisation able to cope with the increasing innovation and flexibility requirement. At this enterprise level, flexible specialisation is characterised as the manufacture of varied products aimed at ever shifting markets and made by skilled, adaptable workers using general purpose machinery.

The concern with innovation and flexibility has, however, extended the analysis from the intra-firm to the inter-firm level. The discovery of dense webs of inter-film linkages outdate analyses which focus on the enterprise as an isolated unit. The main problem for enterprises today is seen as being lonely (Sengenberger and Pyke 1991). Enterprise interaction occurs in clusters amongst equal partners (most developed in industrial districts in the Third Italy), or in vertical sub-contracting arrangements (most developed in 
Japan), or in a combination of both. The term flexible specialisation has been used for all these.

By the same token, the term has been applied to both large and small enterprises (Sabel 1986). In large enterprises the transition to flexible production is achieved through decentralisation into semiautonomous specialised units, new factory layouts (cellular production), just-in-time inventory control and other organisational techniques. These organisational changes are particularly attractive to $\mathrm{LDCs}$ since they are not capital intensive, but research on whether and how they can be implemented in LDCs is still at an early stage. ${ }^{1}$

As indicated above, this Bulletin is concerned more with the small-firm variant of flexible specialisation. The resurgence of small enterprises in developed countries has been a key issue in the debate about flexible specialisation (Sengenberger et al 1990). New computer-based technology has facilitated efficient production on a small scale. Moreover, increasing market segmentation, in consumer markets and in large enterprises' demand, has increased the spaces in which small enterprises can operate. This can be as independent producers, sub-contractors to large firms, and, what has attracted most attention, as cooperating small producers in industrial districts (see Pyke et al 1990). Asheim (1991) advocates that the term flexible specialisation be used only for such small firm industrial districts, but this is by no means a consensus position.

The mounting interest in small enterprises has led to reinterpretations of small enterprises' historical role in Western economies. It has been documented that small enterprises blossomed in certain industrial districts more than a century ago (Sabel and Zeitlin 1985), and that small enterprises in some countries have occupied a more or less constant position in the industrial structure throughout a century of industrialisation (Pedersen 1989). Such analyses substantiate the argument that small enterprises are more than just a 'fashion phenomenon', related to new advanced technologies in industrialised countries.

Finally, flexible specialisation has been used as both an analytical and a prescriptive concept. Using the concept as a prescriptive tool implies that greater flexibility and specialisation is seen as a prospective strategy for industrial development. For example, a country for which such a strategy has been elaborated in a comprehensive and detailed way is Cyprus (Murray et al 1987; 1992). The analytic application of the concept focuses on interpreting industrial organisation along the lines described above.

1 For a case study of the transition from mass production to flexible specialisation in a Cypriot enterprise, see Kaplinsky (1991). On the
Substantial criticism of the concept has been raised. It has been argued that it is 'overly flexible and insufficiently specialised' (Sayer 1989: 666), and that general dichotomies like mass production versus flexible specialisation overstate the changes and fail to grasp continuities of industrial development (Amin and Robins 1990). With respect to the latter critique, it seems of less interest to discuss whether flexible specialisation has replaced mass production. It has not. In reality, the ideal types of flexible specialisation are mixed with other forms of industrial organisation in varying degrees (Hirst and Zeitlin 1991). The point is rather whether the concept helps to grasp processes, which are gaining importance, for example, that flexibility and innovation increasingly become an imperative for enterprises regardless of size.

To conclude, the purpose of this section was to give a brief overview of the various ways in which the concept of flexible specialisation has been used. The variety of its uses has meant that the debate is often messy. As a result, some are inclined to dismiss it. Our view is that the flexible specialisation paradigm has created space for new thinking on industrial organisation and policy. The purpose of this Bulletin is to explore this space in relation to small-scale industry in LDCs.

\section{FLEXIBLE SPECIALISATION: WHY IS IT IMPORTANT IN LDCS?}

One of the main lessons from the 1980s is that competitiveness requires the capacity to adapt to disruptive circumstances. This applies to LDCs even more than to advanced countries (Schmitz 1990). This is likely to continue since $\mathrm{LDCs}$ are now integrated into the world economy to an unprecedented degree. This integration makes the concern with flexible specialisation - at both the research and policy level - more urgent.

The trouble is that most existing large-scale industry in LDCs is rigid and unable to respond to new external and internal markets; even worse it is rarely able to adapt to the frequent interruptions in the supply of inputs. Existing small-scale industry is more flexible, but often trapped in low-profit/low-innovation competition.

In order to become flexible and innovative, new forms of industrial organisation seem to be required in LDCs. There is a danger in seeking the solution in best practice models of developed countries. History tells us that the uncritical transfer of such models leads to bad analysiš and poor practice. This danger is perhaps less severe in the NICs of South-East Asia and Latin America; the adoption of new flexible technologies and

relevance of the new methods of organising production in large Brazilian firms, see Humphrey (1989). 
increasing importance of segmented markets in these countries make the European lessons more applicable (Storper 1991).

However, this is less the case in the poorer economies of South Asia and Africa, where simple technologies and less segmented markets prevail. While small European firms mainly achieve their flexibility from investment in technology and skills, Third World small enterprises are more likely to achieve flexibility in terms of labour utilisation and of combining several business activities, which can be frozen or expanded according to market fluctuations. Similarly, European small firms tend to specialise in narrow market segments by producing a range of highly specialised items, while specialisation in less developed countries tends to occur at a lower level of inter-firm division of labour.

Despite these obvious differences, adopting the flexible specialisation approach can be a step forward in research on small enterprise in LDCs. It leads us to study small enterprises in relation to their sociocultural environment and as integral parts of the entire industrial system.

The tradition of small-scale industry studies in LDCs has basically applied a narrow micro-economic focus on factor utilisation in the individual small enterprise. The small enterprise was regarded as more efficient in poor countries, for being more intensive in the use of labour, which is abundant, instead of scarce capital. Even where this argument is empirically correct it does not challenge the basic reason for large firms' superiority: exploitation of internal economies of scale (Rasmussen 1992). The latter is challenged directly by the flexible specialisation paradigm. It argues that small enterprises can be equally efficient if they can exploit external economies and adjust faster to changing circumstances (Sabel 1986). ${ }^{2}$ This suggests that the links between small enterprises and their environment should be more closely studied. This is an interdisciplinary undertaking as outlined in the next section.

\section{CHALlenges for the ReseARCHER}

So as to bring out some of the methodological issues to be faced in future empirical research, it is useful to reflect briefly on past small enterprise research. Over the last two decades, much of this research was carried out under the informal sector heading. Many informal sector studies applied a cross-section methodology, thus regarding small enterprises as a 'sector' and neglecting the connections to economic agents outside this 'sector'. However, the critique of this methodology is not new. Previous reviews of informal sector studies
(Schmitz 1982; Moser 1984) have brought out the limitations of this approach and advocated branchspecific studies or a sub-sector approach (Boomgard $e t$ al 1991). This implies a focus on the small enterprises' position in relation to suppliers of inputs, distributors of outputs and large competitors. This is now widely recognised and requires little further elaboration (Harris 1990).

The flexible specialisation approach adds four important aspects to this sub-sector approach. First, it includes a location variable. Geographical proximity is considered important to the viability of small enterprises in Europe (Becattini 1989; Garofoli 1991) and LDCs (Courlet 1989; Schmitz 1990).

Second, the relationships between entrepreneurs is influenced by non-economic factors. The denser the web, the more trust and reciprocity matter to the well functioning of a local industrial system. Socio-cultural factors, such as the existence of ethnic, religious or kin groups, have a major influence on how business relations develop (Rasmussen 1992).

Third, explicit attention is given to the role of local institutions in both the public sector (specialised agencies in local or regional government) and the private sector (business associations and producer consortia) (Best 1990; Murray 1991).

Fourth, the flexible specialisation approach emphasises that small enterprises not only react upon an economic and socio-cultural environment. Like its large competitors, but with less power and impact, the small enterprise also acts: it can take chances, it can take good decisions and it can take bad decisions. Varying degrees of success and failure among small enterprises in a given locality or subsector cannot be explained entirely by the impact of economic, political and socio-cultural structures.

The reader might argue that living up to this approach is a tall order. It is. No simple study can give equally thorough attention to all these dimensions. What matters is that they enter the new research agenda. None of them are new in themselves, bringing them together is a collective task.

Whether such research proceeds under the heading of flexible specialisation is of lesser importance. Some readers may rightly feel that the concept has been overstretched. Neither the contributors nor the editors of this Bulletin are all equally comfortable with the concept. However, we all share the view that the flexible specialisation paradigm has blasted open a new trail in small enterprise research. Inevitably there is a 
lot of rubble to be cleared away and a good deal of tidying up to be done before the way forward becomes clearer.

\section{WHAT DOES THIS BULLETIN CONTRIBUTE?}

The purpose of this final section is to introduce the articles contained in this Bulletin. One of their main contributions is to add some empirical substance to the question of how relevant flexible specialisation is to LDCs. It should, however, be pointed out that in almost all cases the authors reflect on this question by reconsidering data which they collected for other purposes. This in itself reflects the fact that we are still in an embryonic stage in this line of research.

The first article by Brigitte Späth focuses on the political-institutional environment, showing why it is often unfavourable for small enterprise activity in LDCs. Using flexible specialisation as a normative approach she draws on the European experiences for identifying what can be done to facilitate the emergence of small firm communities in Third World countries. Although changes in national policies are important, sustainable small enterprise development also requires initiatives which can fuel the mobilisation of local community resources into business development.

There follow five contributions drawing on empirical evidence from African countries. In his article, Anders Aeroe follows Späth in distinguishing between a normative and a positive approach to flexible specialisation. Aeroe considers the development of small enterprises in a rapidly growing Tanzanian town in relation to the pursued national top-down industrialisation strategy. Despite a large variation a mong the small enterprises with respect to investment strategy and product quality, the general level of interfirm linkages is low. From the normative perspective he advocates the need to narrow the gap between the small and large enterprise in the national industrial structure.

Jesper Rasmussen applies flexible specialisation as an analytical approach in a study of small enterprises in three Zimbabwean towns. He examines local competition and specialisation between large and small enterprises and assesses the impact of the socio-cultural environment on enterprise success. Small enterprises face a double weakness: resting on a fragile local network and competing against large, white-owned firms with decades of accumulated know-how. The conclusion is that an increased spill-over of knowledge from large to small enterprises would have more impact on small enterprise development than the emergence of independent small enterprise clusters.

In a study of carpentry enterprises in two regions in Kenya and Zimbabwe Arni Sverrisson uses flexible specialisation to assess the degree to which the enterprises resemble the ideal type. He describes various forms of enterprise cooperation among small enterprises of different degrees of sophistication, but emphasises both the volatile character of the enterprise networks and the atomised way of operation. Sverrisson concludes that a flexible specialisation approach can reveal new insights to small enterprises but that more conceptual work has to be done on issues like conflict, hierarchy and inequality.

Jonathan Dawson applies the flexible specialisation approach to a cluster of small enterprises in the town Kumasi in Ghana. He describes the growth of small enterprises in the aftermath of the decline of large firms and notes their considerable resilience even after imports have been liberalised. However, increasing competition among small firms, especially in branches with low entry barriers, seems to limit their further growth. Only engineering firms resemble the ideal type of flexible specialisation.

Dirk Hansohm uses the ideal type of flexible specialisation for assessing small enterprises in a medium-sized town in Sudan. Deteriorating macroeconomic conditions during the 1980 s have heightened the inefficiency of large firms, but small enterprises are still unable to prosper since macro-policies remain biased in favour of these large firms. From a study of small enterprises in four sub-sectors Hansohn concludes that despite flexibility in labour use and product range they show few signs of inter-firm cooperation and innovative behaviour. Consequently flexible specialisation is still an inappropriate term for these enterprises.

Meine Pieter van Dijk derives similar conclusions from his research in Ouagadougou, Burkina Faso. Informal sector enterprises rarely show the traits associated with flexible specialisation. They use other mechanisms to survive in a very competitive environment. Amongst formal sector industrial enterprises, a limited number of cases display characteristics associated with flexible specialisation. The economic crisis of the 80 s has forced them to work in a new way. Van Dijk also makes recommendations on how flexible specialisation can be promoted.

Like Dawson, Ines Smyth also interprets an agglomeration of small enterprises through the lens of flexible specialisation. Small rattan manufacturers in a small town in Indonesia have experienced considerable growth since exports of raw rattan was prohibited in the late 1970s. Smyth discerns three types of small enterprises and discusses their different insertion in the overall division of labour between small and large enterprises. She concludes that clustering has resulted in collective efficiency but that the benefits have 
accrued unevenly to firms of different size and to different categories of workers.

Fiona Wilson makes a somewhat similar point in a historical study of small garment producers. She describes the rise and decline of collective efficiency in a Mexican town, starting with small businesses established by returning migrants and gradually developing into a myriad of smaller and larger enterprises. In this process the social basis of collectivity has been undermined by increasing differentiation among the enterprises. Thus, overall production in the local industry may continue to grow and spread, but the structures which give rise to this dynamic are being dismantled by the very process of growth, and a new foundation for industrialisation arises.
Finally Hubert Schmitz suggests a line of research on the small firm variant of flexible specialisation and puts forward a few categories which may help to disentangle the issue of the economic viability of small firms in LDCs. His starting point is the difference between dispersed and clustering producers, since there is a substantial difference in the dynamic governing their viability. Clustering facilitates gains in efficiency and flexibility which are rarely attainable by individual firms. The concept of collective efficiency is put forward to capture these gains. In future research it is suggested to distinguish between clusters which are hierarchical and those in which equals compete or cooperate; and between stages in which collective efficiency comes about spontaneously and in which it results from planned action.

\section{REFERENCES}

Amin, A. and Robins, K., 1990, 'The reemergence of regional economies? The mythical geography of flexible accumulation', Society and Space, Vol 8

Asheim, B. T., 1991, 'Flexible specialisation, industrial districts and small firms: a critical appraisal', in $\mathrm{H}$. Ernst and V. Meier (eds), Regional Development and Contemporary Industrial Response: Extending Flexible Specialisation, Belhaven Press, London

Becattini, G., 1989, 'Sectors and/or districts: some remarks on the conceptual foundations of industrial economies', in E. Goodman and F. Bamford (eds)

Best, M. H., 1990, The New Competition: Institutions of Industrial Restructuring, Polity Press, Cambridge

Boomgard, J. J., Davies, S. P., Haggblade, S. J. and Mead, D. C., 1991, 'A subsector approach to small enterprise promotion and research', Gemini Working Paper No 10 , Gemini, Washington DC, January

Courlet, C., 1989, 'Les industrialisations endogènes', Revue Tiers Monde, No 118

Garofoli, G., 1991, Modeli Locali di Svilupo, Franco Angeli, Milano

Goodman, E. and Bamford, F. (eds.) 1989, Small Firms and Industrial Districts in Italy, Routledge, London

Harris, J., 1990, 'Linkages between the formal and the informal sectors in developing countries: a review of the literature', WEP2-19/W.P.50, Workiung Paper, World Employment Programme, ILO, Geneva

Hirst, P. and Zeitlin, J., 1991, 'Flexible specialisation versus post-Fordism: theory, evidence and policy implications', in Economy and Society, Vol 20 No l

Humphrey, J., 1989, 'New forms of work organisation in industry: their implications for labour use and control in Brazil', mimeo, Institute of Development Studies, Sussex
Kaplinsky, R., 1990, The Economies of Small: Appropriate Technology in a Changing World, IT Publications, London

-1991, 'From mass production to flexible specialisation: a case study from a semi-industrialised economy', IDS Discussion Paper 295, Institute of Development Studies, Sussex, November

Moser, C., 1984, 'The informal sector reworked: viability and vulnerability in urban development', Regional Development Dialogue, Vol 5 No 2, Autumn

Murray, R., et al, 1987, 'Cyprus industrial strategy', Report of UNDP/UNIDO Mission, Institute of Development Studies, Sussex, November

-1991, Local Space: Europe and the New Regionalism, Centre for Local Economic Strategies, Manchester, and South East Economic Development Strategy, Hertfordshire

-1992 , 'Flexible specialisation in small island economies: the case of Cyprus', in F. Pyke and W. Sengenberger (eds)

Pedersen, P. O., 1989, 'The role of small enterprises and small towns in the developing countries - and in the developed', CDR Project Paper 89.1, Centre for Development Research, Copenhagen

Piore, M. and Sabel, C., 1984, The Second Industrial Divide: Possibilities for Prosperity, Basic Books, New York

Pyke, F., Becattini, G. and Sengenberger, W. (eds), 1990, Industrial Districts and Inter-firm Cooperation in Italy, International Institute for Labour Studies, Geneva

Pyke, F. and Sengenberger, W. (eds), 1992, Industrial Districts and Local Economic Regeneration, International Institute for Labour Studies, Geneva

Rasmussen, J., 1992, 'Entrepreneurial milieu: enterprise networks in small Zimbabwean towns', Research Report No 79, Department of Geography, Roskilde University in cooperation with the Centre for Development Research, Copenhagen 
Sabel, C., 1986, 'Changing models of economic efficiency and their implications for industrialisation in the Third World', in A. Foxley, M. McPherson and G. O'Donnell (eds), Development, Democracy and the Art of Trespassing, University of Notre Dame Press

-and Zeitlin, J., 1985, 'Historical alternatives to mass production: politics, markets and technology in nineteenthcentury industrialisation', Past and Present, No 108

Sayer, A., 1989, 'Post Fordism in question', International Fournal of Urban and Regional Research, Vol 13 No 4

Schmitz, H., 1982, 'Growth constraints on small-scale manufacturing in developing countries: a critical review', World Development, Vol 10 No 6
-1990, 'Small firms and flexible specialisation in developing countries', Labour and Society, Vol 15 No 3

Sengenberger, W., Loveman, G. and Piore, M. (eds), 1990, The Reemergence of Small Enterprises: Industrial Restructuring in Industrialised Countries, International Institute for Labour Studies, Geneva

-and Pyke, F., 1991, 'Small firm industrial districts and local economic regeneration: research and policy issues', Labour and Sociery, Vol 16 No 1

Storper, M., 1991, Industrialisation, Economic Development and the Regional Question in the Third World, Pion, London 